\title{
PENINGKATAN KETERAMPILAN MENULIS DESKRIPSI DENGAN TEKNIK TANYA JAWAB BERBANTUAN MEDIA GAMBAR SISWA KELAS VIII 3 SMP N 2 SUNGAYANG KABUPATEN TANAH DATAR
}

\author{
Oleh: \\ Desmike Putri Ayu ${ }^{1}$, Atmazaki², Amril Amir ${ }^{3}$ \\ Program Studi Pendidikan Bahasa dan Sastra Indonesia \\ FBS Universitas Negeri Padang \\ email: mike ayu@rocketmail.com
}

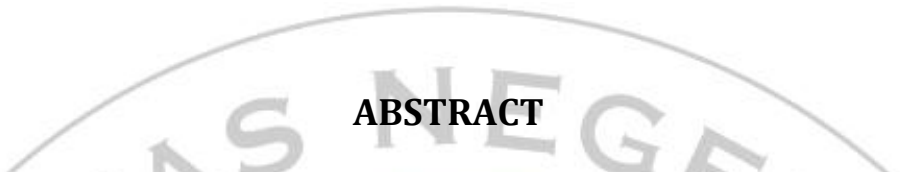

This research is aimed to explain about the process of using asking-answering technique with the help of picture as media in improving writing ability of descriptive text in the third grade students of SMP 2 Sungayang.This research is a Class Action Research and qualitative research (class action research) that involves: (1) action planning (2)action implementing (3) result observation, and (4) reflection. This research is implemented in two cycles, they are cycle 1 and cycle 2 . Ctcle 2 is implemented based on evaluation result at cycle 1 . Researcher as presenter in the process of learning, whereas as observer and collaborator is an Indonesian Language teacher in the third grade class of SMP 2 Sungayang.The result of the research shows using asking- answering technique with the help of picture as media in teaching writing descriptive text is effective to improve students' ability in writing descriptive text. From the result of this class action research, it can be taken a conclude that teaching writing descriptive text by using asking-answering with the help of picture as media improve students' learning result of the third grade students of SMP 2 Sungayang.

Kata kunci: menulis deskripsi; media gambar; teknik tanya jawab

\section{A. Pendahuluan}

Pembelajaran bahasa Indonesia bertujuan untuk meningkatkan empat aspek keterampilan berbahasayakni menyimak, berbicara, membaca, dan menulis.Walaupun menulis menduduki posisi paling akhir, tetapi menulis mempunyai banyak fungsi yang sangat penting bagi pengembangan intelektual seseorang, salah satunya yaitu untuk mengemukakan sesuatu. Melalui keterampilan menulis, siswa dapat mengekspresikan pikiran, ide, serta gagasan kepada orang lain.

Keterampilan menulis merupakan pengungkapan ide, gagasan, pikiran atau perasaan secara tertulis. Untuk menulis, ide atau gagasan bisa timbul dengan membaca dan melakukan pengamatan secara langsung atau tidak langsung terhadap suatu pokok permasalahan atau suatu peristiwa. Hal ini akan menimbulkan suatu pemikiran baru untuk ditulis. Keterampilan

\footnotetext{
${ }^{1}$ Mahasiswa penulis skripsi Prodi Pendidikan Bahasa dan Sastra Indonesia, wisuda periode September 2012

2 Pembimbing I, Dosen FBS Universitas Negeri Padang

3 Pembimbing II, Dosen FBS Universitas Negeri Padang
} 
menulis secara langsung dapat dimiliki oleh siswa, tetapi harus melalui latihan dan praktik yang teratur.

Bentuk keterampilan menulis yang diajarkan kepada siswa adalah menulis karangan narasi, deskripsi, eksposisi, argumentasi, dan persuasi. Dalam hal ini penulis memilih karangan deskripsi karena deskripsi merupakan alat bantu yang efektif untuk lebih menghidupkan pokok pembicaraan, untuk menghindari rasa kebosanan dan keengganan para pembaca. Dalam proses belajar mengajar siswa dituntut untuk bisa menulis. Pentingnya keterampilan menulis di sekolah menuntut siswa untuk dapat membuat sebuah tulisan, salah satu jenis tulisan yaitu deskripsi. Tulisan deskripsi merupakan tulisan yang berkaitan dengan pengalaman panca indra, seperti penglihatan, pendengaran, perabaan, penciuman dan perasaan. Tulisan deskripsi ini memberikan suatu gambaran tentang suatu peristiwa atau kejadian.

Keterampilan menulis deskripsi tercantum dalam Kurikulum Tingkat Satuan Pendidikan (KTSP) untuk SMP/MTs kelas VIII. Standar Kompetensi yang dicantumkan KTSP untuk menulis deskripsi, yaitu mengungkapkan informasi dalam bentuk laporan, surat dinas, dan petunjuk. Kompetensi dasar yang harus dicapai yaitu menulis laporan dengan menggunakan bahasa yang baik dan benar. Keterampilan ini diberikan agar siswa mampu menulis berbagai macam keterampilan berbahasa. Sesuai kurikulum, siswa SMP Negeri 2 Sungayang telah belajar keterampilan menulis dan siswa diharapkan memiliki keterampilan menulis yang baik terutama menulis tulisan deskripsi.Menurut Tarigan (2008:3) menulis merupakan keterampilan berbahasa yang dipergunakan untuk berkomunikasi secara tidak langsung, tidak secara tatap muka dengan orang lain. Menulis merupakan suatu kegiatan yang produktif dan ekspresif.

Kegiatan menulis atau mengarang pada hakekatnya merupakan pemindahan pikiran atau perasaan ke dalam bentuk lambang-lambang bahasa. Biasanya perasaan dan pikiran disampaikan secara lisan, karena menulis tidak lain merupakan upaya memindahkan bahasa lisan ke dalam wujud tulisan dengan menggunakan lambang-lambang grafem. Tulisan yang dapat dikatakan berhasil adalah tulisan yang dapat dipahami dengan mudah oleh pembaca. Segala ide dan pesan yang disampaikan harus dipahami secara baik oleh pembacanya, tafsiran pembaca sama dengan maksud penulis. Untuk mencapai ini, memang memerlukan latihan dan pengalaman Semi (2009:2-3).

Sementara, menurut Tarigan (2008:22) menulis adalah menurunkan atau melukiskan lambang-lambang grafik yang menggambarkan suatu bahasa yang dipahami oleh seseorang, sehingga orang lain dapat membaca lambang-lambang grafik tersebut kalau mereka memahami bahasa dan gambaran grafik itu. Menulis merupakan suatu representasi bagian dari kesatuankesatuan ekspresi bahasa. Sejalan dengan itu, Semi (2009:6) mengemukakan bahwa menulis merupakan suatu proses yang kreatif. Sebagai suatu proses yang kreatif, menulis harus mengalami suatu proses yang secara sadar pula dilihat hubungan satu dengan yang lain, sehingga berakhir pada suatu tujuan yang jelas.

Menurut Tarigan (2008:20) tulisan dipergunakanoleh orang-orang terpelajar untuk merekam, meyakinkan, melaporkan, serta mempengaruhi orang lain, dan maksud serta tujuan tersebut hanya bisa tercapai dengan baik oleh orang-orang (penulis) yang dapat menyusun pikirannya serta mengutarakannya dengan jalas (mudah dipahami). Bahkan kemajuan suatu bangsa atau Negara ditentukan oleh kemajuan komunikasi tulisnya. Komunikasi tulisan dapat diukur dari kualitas dan kuantitas para pengarang beserta hasil karyanya turut menentukan kemajuan suatu bangsa.Hal ini sejalan dengan pendapat Thahar (2008:12) yang mengatakan kegiatan menulis adalah kegiatan intelektual.Seorang yang intelektual ditandai dengan kemampuannya mengekspresikan pikirannya melalui tulisan dengan media bahasa yang sempurna.

Sebelum mulai menulis, kita harus mengetahui tujuan dari menulis tersebut karena menulis itu merupakan pekerjaan yang memerlukan waktu, pemikiran dan suatu pekerjaan yang dilakukan dengan dorongan yang kuat. Dorongan itu muncul karena adanyan tujuan yang jelas. Disamping itu, kesempatan untuk sukses dalam menulis akan terbuka lebar apabila penulis memahami tujuan menulis. Menurut Semi (2009:17) secara umum tujuan menulis itu adalah 
pertama Memberikan arahan, yakni memberikan petunjuk kepada oranglain dalam mengerjakan sesuatu. Kedua Menjelaskan sesuatu, yakni memberikan uraian tentang suatu hal yang harus diketahui oleh orang lain. Ketiga Menceritakan kejadian, yaitu memberikan informasi tentang sesuatu yang berlangsung di suatu tempat di suatu waktu. Keempat Meringkaskan, yaitu membuat rangkuman suatu tulisan sehingga menjadi lebih singkat. Kelima Meyakinkan, yaitu tulisan yang berusaha meyakinkan agar orang lain sependapat dengannya.

Langkah-langkah dalam menulis adalah sebagai berikut: (1) Pemilihan dan Penetapan Topik. Memilih dan menetapkan topik merupakan suatu langkah awal yang penting, sebab tidak ada tulisan tanpa ada sesuatu yang hendak ditulis. Topik tulisan adalah masalah atau gagasan yang hendak disampaikan di dalam tulisan. Masalah atau gagasan itu dapat diperoleh atau digali melalui empat sumber yaitu pengalaman, pengamatan, imajinasi, serta pendapat dan keyakinan. (2) Pengumpulan Informasi. Pengumpulan informasi dan data ini perlu dilakukan agar tulisan tersebut menjadi tulisan yang berbobot dan meyakinkan. Informasi dan data yang dikumpulkan itu adalah informasi dan data yang relevan dengan topik atau pokok bahasan dan sesuai pula dengan tujuan tulisan. Data dan informasi itu dapat berupa gambar, statistik, grafik, atau beberapa cuplikan orang lain.

(3) Penetapan Tujuan. Penetapan tujuan pada dasarnya sudah mulai tertanam di dalam pikiran penulis disaat pemilihan dan penetapan topik dilakukan, namun tujuan itu harus lebih didasari pada saat tulisan itu mulai dirancang dengan sungguh-sungguh. Bila suatu tujuan tidak dilandasi oleh tujuan yang jelas dan tegas dapat menyebabkan tulisan itu tanpa arah yang jelas, dan besar kemungkinan menjadi tulisan yang tidak berhasil atau tidak dipahami pembaca. (4) Perancangan Tulisan. Merancang tulisan dapat diartikan sebagai suatu kegiatan menilai kembali informasi dan data, memilih sub topik yang perlu dimuat, melakukan pengelompokan topiktopik kecil ke dalam suatu kelompok yang lebih besar, dan memilih suatu sistem notasi dan sistem penyajian yang dianggap paling baik. Hasil merancang tulisan ini, antara lain akan berwujud sebagai kerangka tulisan (outline) dan penetapan gaya penyajian tulisan.

(5) Penulisan. Di dalam penulisan perlu dipilih organisasi dan sistem penyajian yang tepat. Artinya, tepat menurut jenis tulisan, tepat menurut topik, dan tepat menurut tujuan dan sasaran tulisan. Di dalam melahirkan pikiran atau gagasan hendaknya menggunakan bahasa yang hidup dan lancar sebagai mediumnya. Di dalam pemanfaatan bahasa ini tentu saja dilakukan dengan cara yang paling baik, dengan jalan menggunakan ejaan dan tanda baca secara tepat, memilih kata (diksi), dan menggunakan kalimat yang efektif. (6) Penyuntingan atau Revisi. Di dalam menyunting dilakukan kegiatan mengecek ketepatan angka-angka atau nama, menghilangkan yang tidak perlu, menambah sesuatu yang perlu ditambah. Disamping itu dilakukan pula perbaikan kalimat dan ejaan. Kosa kata yang kurang tepat diganti dengan yang lebih tepat. Cara menyunting yang paling baik adalah dengan membiarkan tulisan itu terendap beberapa waktu setelah penulisan, dan kemudian melakukan suntingan dengan membaca teliti, serta menganggap bahwa tulisan yang dihadapi sewaktu menyunting itu adalah tulisan orang lain. (7) Penulisan Naskah Jadi. Setelah penyuntingan tentu saja harus ditulis kebali agar menjadi tulisan yang selesai, rapi, dan bersih. Dalam pengetikan terakhir ini perlu diperhatikan kembali masalah ejaan dan tanda baca. Masalah perwajahan harus pula mendapat perhatian yang sungguhsungguh, karena kesempurnaan sebuah tulisan tidak hanya terbatas pada kesempurnaan isi dan ketepatan pemakaian perangkat kebahasaan, tetapi juga masalah susunan, kejelasan ,dan ketepatan pemakaian sarana tulis lainnya. Kerapian dan keindahan tata muka memberi nilai tambah terhadap kesempurnaan tulisan.

Menurut Semi (2009:56-57), deskripsi adalah tulisan yang tujuannya memberikan informasi tentang suatu objek secara detail atau rinci sehingga memberikangambaranyang jelas yang berdampak mempengaruhi emosi dan imajinasi pembaca bagaikan ikut melihat atau mengalami langsung hal tersebut.Untuk menghasilkan tulisan deskripsi yang baik, haruslah penulisannya memahami detail yang berkenaan dengan objek tulisan sehingga dapat disajikan dengan hasilnya bagaikan kenyataan yang sebenarnya. 
Hal ini sejalan dengan pendapat Thahar (2008:36) yang mengatakan karangan deskripsi adalah pemaparan atau penggambaran dengan kata-kata tentang sesuatu, berupa benda, tempat, dan suasana atau keadaan. Melalui karangan deskripsi pembaca dapat melihat apa yang dilihat pengarang dalam karangan itu merasakan dan membaui apa yang dirasakan dan dibaui oleh pengarang. Seakan-akan karangan deskripsi itu hidup jika ditulis oleh seorang pengarang yang memiliki kemampuan dan pengamatan yang tajam serta pemilihan kata yang tepat guna atau dengan perbandingan yang cocok.Sementara itu Atmazaki (2006:88) mengatakan, "Deskripsi merupakan bentuk tulisan yang melukiskan suatu objek (tempat, benda, dan manusia)".

Sedangkan menurut Marahimin (2010:45), deskripsi adalah pemaparan atau penggambaran dengan kata-kata suatu benda, tempat, suasana, atau kedaaan.Seorang penulis deskripsi mengharapkan pembacanya, melalui tulisannya, dapat melihat apa yang dilihatnya, dapat mendengar apa yang didengarnya, mencium bau yang diciumnya, mencicipi apa yang dimakannya, merasakan apa yang dirasakannya, serta sampai kepada kesimpulan yang sama dengannya.Menurut Semi (2009:57), ciri penanda yang sekaligus pembeda deskripsi dengan eksposisi adalah sebagai berikut. Pertama, tulisan deskripsi bertujuan untuk menyampaikan informasi tentang objek secara rinci sehingga sangat jelas bagi pembaca.Kedua, tulisan deskripsi lebih bersifat mempengaruhi emosi atau mempersuasi pikiran, serta memancing imajinasi pembaca.Ketiga, tulisan deskripsi disajikan dengan gaya memikat dan dengan pilihan kata yang menggugah. Keempat, tulisan deskripsi umumnya menyangkut objek yang dapat dilihat, didengar, atau dirasakan sehingga objeknya pada umumnya tentang benda, gedung, panorama, dan manusia.

Berdasarkan ciri-ciri karangan deskripsi yang telah dikemukakan di atas, maka karangan deskripsi dapat dibagi dua.Seperti yang dikemukakan Achmadi (1988: 106) bahwa menurut beberapa analisis ada dua jenis karangan deskriptif, yaitu deskripsi teknis dan deskripsi sugestif. Pendapat yang sama dikemukakan Semi (2009:58) karangan deskripsi dibagi atas dua jenis, yaitu: (I) deskripsi ekspositorik (deskripsi teknis), (2) deskripsi artistik (deskripsi sugestif). Sementara itu Keraf (1982:94) juga membedakan deskripsi menjadi dua yaitu deskripsi sugestif dan deskripsi teknis.

Menurut Semi (2009:71), langkah-langkah atau petunjuk-petunjuk menulis karangan deskripsi adalah sebagai berikut: pertama, Pilih dan perhatikan detail (rincian) dengan teliti. Maksudnya, sebelum penulis menggambarkan atau melukiskan tentang suatu objek, masalah peristiwa atau kejadian harus dipahami terlebih dahulu seluk-beluk objek masalah peristiwa atau kejadian yang akan digambarkan atau dilukiskan. Pilihlah detail (rincian) yang memang sangat baik untuk dipaparkan. Detail harus disusun dengan sistematis. Misalnya, mulai dan belakang ke depan, atau dari kiri ke kanan, atau dan sudut pandangan tertentu kepada sudut pandang yang lain. Jangan sampai bolak-balik dan hilir mudik, sehingga membingungkan.

Kedua, Gunakanlah pilihan kata yang tepat. Maksudnya, penulis hendaknya menguasai dengan baik terutama menyangkut diksi dan gaya bahasa sehingga apa yang disajikan dalam tulisan itu benar-benar mewakili atau sesuai dengan objeknya. Dalam sebuah karangan deskripsi diksi dan gaya bahasa yang tepat sangat diperlukan karena akan memberikan impresi dan imajinasi, serta menggugah pembaca. Penggunaan diksi dan gaya bahasa yang tepat juga akan mendukung apa yang diamati dan dirasakan penulis, juga dapat diamati dan dirasakan oleh pembaca. Oleh sebab itu, gunakanlah ungkapan atau kata yang spesifik (kata yang secara khusus dipakai untuk suatu benda atau nama tertentu). Janganlah menggunakan istilah yang sangat umum karena istilah yang umum tidak ada memancing kesan yang khas.Kata yang spesifik itu seperti kursi, anjing, mangga, nasi, sedangkan kata yang umum itu seperti perabot, binatang, buah-buahan, makanan. Misalnya, bila penulis hendak menggambarkan kejorokan sebuah kamar mandi atau WC, jangan menggunakan ungkapan seperti "kotoran manusia berserakan di mana-mana", tetapi gunakan istilah yang lebih khusus seperti "taik dan kencing berserakan di mana-mana". Dengan demikian, lebih mungkin memberikan impresi atau menggugah perasaan pembaca Semi (2009:72). 
Menurut Sadiman (2007:28) alat bantu pandang berfungsi untuk memperkuat dan memadukan gambaran bunyi, tata bahasa, kosakata, dari dalam kepala siswa, serta untuk menanamkan pengertian. Selain itu, alat bantu pandang juga berfungsi untuk menyampaikan pesan dari sumber ke penerima pesan. Saluran yang digunakan menyangkut indera penglihatan. Pesan yang akan disampaikan dituangkan ke dalam simbol-simbol komunikasi visual. Simbolsimbol tersebut perlu dipahami benar artinya agar proses penyampaian pesan dapat berhasil dengan efisien.

Alat bantu pandang yang dapat digunakan dalam pengajaran bahasa dan sastra Indonesia misalnya, gambar/foto, sketsa, diagram, bagan/chart (chart gambar dan chart kantong), grafik, kartun, poster, papan tulis, papan flannel, papan bulletin, kartun gambar, dan lain-lain. Adapun contoh media visual tersebut, gambar/foto adalah media yang paling umum dipakai. Media gambar merupakan bahasa yang umum dapat dimengerti dan dinikmati dimana-mana.

Berikut akan diuraikan beberapa kelebihan media gambar/foto menurut Sadiman (2007:29-31) yakni (1) sifatnya konkret, gambar lebih mampu menunjukan pokok permasalahan secara realitis, (2) gambar dapat mengatasi batasan ruang dan waktu, tidak semua objek atau benda dapat dibawa ke kelas dan tidak selalu bisa anak-anak dibawa ke tempat atau objek tersebut, untuk itu gambar dapat mengatasinya, (3) media gambar atau foto dapat mengatasi keterbatasan pengamatan manusia, misalnya sel atau penampang daun yang tidak mungkin dilihat dengan panca indera, dengan bantuan gambar hal tersebut dapat diamati, (4) dapat memperjelas suatu masalah, (5) murah harganya dan gampang didapat serta digunakan.

Menurut Saliwangi (1989:56) ada beberapa teknik-teknik pengajaran yaitu: (1) ceramah. Artinya, teknik ceramah memang bisa digunakan untuk menyampaikan informasi, terutama kepada siswa terhadap apa yang dipikirkan atau isi bacaan yang sudah dipercaya, (2) tanya jawab, menilai tingkat pemahaman siswa terhadap apa yang dipikirkan atau isi bacaan yang sudah dibacanya, (3) diskusi kelompok, diskusi kelompok dilaksanakan untuk saling mengemukakan pendapat mengenai suatu hal tertentu dan dapat menguji beberapa pendapatnya mengenai sesuatu hal, (4)pemberian tugas, pemberian tugas dilakukan untuk siswa sehingga lebih mendalami materi pelajaran yang diberikan. Hasilnya sekaligus berfungsi untuk mengukur sampai seberapa jauh siswa telah memperoleh pengetahuan ataupun keterampilan yang sudah disajikan, (5)studi kasus, teknik ini digunakan untuk menganalisis suatu masalah dan menari kemungkinan pemecahannya. (6) Brainstoring, teknik ini dapat membangkitkan pikiran yang kreatif, merangsang partisipasi siswa, memancing timbulnya pendapat-pendapat baru, dan menciptakan suasana senang dalam kelompok, (7) eksperimen, mendemonstrasikan secara langsung materi yang akan diajarkan kepada siswa, (8) Simulasi dipergunakan untuk latihan agar siswa dapat menerapkan pada keadaan yang sesungguhnya, (9) sosiodrama,teknik ini untuk melatih siswa menghayati suatu kejadian tertentu sekalipun dalam bentuk tiruan.

Diantara contoh dari teknik pengajaran tersebut, teknik tanya jawab adalah teknik yang sering digunakan dalam proses belajar mengajar dan ini merupakan langkah pertama dalam pengajaran satu arah, serta teknik ini sering di gunakan dalam menyampaikan materi kepada siswa untuk menghilangkan kejenuhan pada siswa.Menurut Santosa (2003:16), tujuan teknik tanya jawab yaitu; (1) siswa dapat mengerti dan mengingat kembali materi yang dipelajari, didengar atau dibaca, (2) Siswa dapat berfikir secara kronologis atau runtun, (3) siswa dapat mengetahui taraf pengetahuan dan pemahaman, (4) siswa dapat memahami bacaan.

Untuk mengetahui peningkatan keterampilan menulis deskripsi siswa, teknik yang digunakan adalah teknik tanya jawab yang dibantu dengan media gambar. Dengan menggunakan teknik tanya jawab dapat menilai tingkat pemahaman siswa terhadap apa yang dipikirkan atau isi bacaan yang sudah dibacanya dan media gambar dapat menunjukan pokok permasalahan secara realitisSadiman (2007:29-31). Jadi untuk mengetahui peningkatan keterampilan menulis deskripsi siswa dapat ditempuh dengan menggunakan teknik tanya jawab dibantu dengan media gambar. 
Berdasarkan uraian di atas,penelitian ini bertujuan untuk menjelaskan proses dan hasil peningkatan keterampilan menulis karangan deskripsi berbantuan media gambar siswa kelas VIII 3SMP Negeri 2 Sungayang.

\section{B. Metode Penelitian}

Penelitian ini merupakan Penelitian Tindakan Kelas dengan menggunakan pendekatan kualitatif yang bersifat deskriptif.Menurut Arikunto (2006:3) penelitian tindakan kelas merupakan suatu pencermatan terhadap kegiatan belajar berupa sebuah tindakan yang sengaja dimunculkan dan terjadi dalam sebuah kelas yang secara bersama. Metode deskriptif merupakan suatu metode yang bertujuan untuk mendeskripsikan dan memberikan gambaran secara umum tentang hasil tulisan yang dibuat oleh siswa. Metode deskripsi ini dilakukan dengan cara mengumpulkan, menyusun, mengklasifikasi, serta menganalisis data.

Penelitian tindakan kelas merupakan sebuah tindakan analisis yang diawali dari upaya menemukan fakta melalui pengamatan, merencanakan, melakukan tindakan, menemukan masalah dan mengevaluasi temuan. Menurut Arikunto (2006:16), ada empat langkah utama dalam penelitian tindakan yakni: 1) perencanaan, 2) pelaksanaan, 3) pengamatan, dan 4) refleksi. Siklus ini dimulai dengan pengamatan dan perencanaan tindakan, pelaksanaan tindakan, pengobservasian hasil tindakan dan pelaksanaan refleksi.

Penelitian tindakan kelas ini akan dilaksanakan di kelas VIII 3 SMP Negeri 2 Sungayang. Subjek penelitian ini adalah siswa kelas VIII 3dengan jumlah 30 orang.Mitra peneliti dalam penelitian ini adalah guru kelas VIII di SMP Negeri 2 Sungayang.Instrumen yang digunakan dalam penelitian ini terdiri atas tiga jenis, yaitu tes, angket, dan lembaran observasi. Data penelitian ini dikumpulkan dengan menggunakan angket, tes, lembaran dan observasi. Setelah data terkumpul, teknik analisis data yang dilakukan adalah dengan mengelompokan data dan pemberian skor.

\section{Pembahasan}

Pada pembelajaran menulis karangan deskripsi dengan teknik tanya jawab dibantu dengan media gambar yang dilakukan terungkap bahwa siswa sebagai sampel dalam penelitian ini masih banyak yang belum mengerti tentang deskripsi sehingga pada awal pertemuan atau prasiklus peneliti memberikan penjelasan sedikit mengenai tulisan deskripsi. Selanjutnya siswa langsung dilatih menulis deskripsi dengan topik bebas. Kegiatan kurang berjalan dengan baik. Dalam proses belajar mengajar, siswa dikelas tidak dapat diatur, hal ini terjadi karena lebih dari setengah jumlah siswa tidak mengerti dengan apa yang akan mereka tulis mengenai tulisan deskripsi. Sehingga siswa selalu bertanya dengan teman maupun guru tentang deskripsi. Ratarata dari hasil prasiklus ini adalah 30,4\% dan berada pada klasifikasi kurang sekali.

Berdasarkan uraian tersebut, maka peneliti menyusun strategi belajar mengajar untuk membuat siswa lebih memahami tentang tulisan deskripsi. Salah satu strategi yang digunakan adalah dengan pemilihan salah satu teknik pengajaran bahasa. Dalam penelitian ini, peneliti telah mencoba menggunakan teknik tanya jawab dengan media gambar. Teknik atau media yang dipilih dalam pembelajaran menulis diharapkan dapat mengatasi kesulitan yang dialami siswa. Siswa lebih mudah menuangkan ide, pikiran, imajinasi dan perasaan ke dalam tulisan. Untuk mengubah skor menjadi nilai ini Abdurrahman dan Ratna (2003:262) mengatakan dapat menggunakan rumus persentase berikut ini :

$$
\mathrm{N}=\mathrm{SM} \times \mathrm{S} \max
$$

SI

Keterangan :

$\mathrm{N} \quad$ : tingkat penguasaan

SM : skor yang diperoleh

SI : skor yang harus dicapai dalam suatu tes

$\mathrm{S}$ max : skala yang digunakan 
Selanjutnya dengan mengelompokkan data kuantitatif berdasarkan skala 10 berikut.

Tabel 1: Penentuan Patokan Dengan Perhitungan Persentase untuk Skala 10

\begin{tabular}{|c|c|c|}
\hline Tingkat Penguasaan & Nilai Ubahan Skala 10 & Kualifikasi \\
\hline $96-100 \%$ & 10 & Sempurna \\
\hline $86-95 \%$ & 9 & Baik Sekali \\
\hline $76-85 \%$ & 8 & Baik \\
\hline $66-75 \%$ & 7 & Lebh Dari Cukup \\
\hline $56-65 \%$ & 6 & Cukup \\
\hline $46-55 \%$ & 5 & Hampir Cukup \\
\hline $36-45 \%$ & 4 & Kurang Sekali \\
\hline $26-35 \%$ & 3 & Buruk \\
\hline $16-25 \%$ & 2 & Buruk Sekali \\
\hline $0-15 \%$ & 1 & Abuurahman \\
\hline
\end{tabular}

(Abdurrahman dan Ratna, 2003:265)

Langkah berikutnya dengan menentukan kemampuan rata-rata menulis karangan deskripsi dengan teknik tanya jawab. Menurut Abdurrahman dan Ratna (2003 : 270) untuk mencari rata-rata hitung menggunakan rumus berikut ini :

$$
\begin{aligned}
& \mathrm{M}=\frac{\sum \mathrm{FX}}{\mathrm{N}} \\
& \mathrm{M}=\text { mean (rata-rata) } \\
& \mathrm{F}=\text { frekuensi } \\
& \mathrm{X}=\text { skor } \\
& \mathrm{N}=\text { jumlah siswa }
\end{aligned}
$$

Dari hasil siklus I yang telah dilakukan rata-rata untuk indikator (1) memberikan detail atau perincian objek adalah $67,3 \%$ dan berada pada klasifikasi lebih dari cukup, (2) memberi pengaruh sensivitas dan imajinasi adalah $60 \%$ dan berada pada klasifikasi cukup, (3) pemilihan diksi yang menggugah dan memikat adalah $61,3 \%$ dan berada pada klasifikasi cukup, (4) memaparkan sesuatu yang dapat didengar, dilihat, dan dirasakan adalah $60 \%$ dan berada pada klasifikasi cukup, (5) ejaan yang disempurnakan adalah 59,3\% dan berada pada klasifikasi cukup. Rata-rata dari siklus I adalah $61,6 \%$ dan berada pada klasifikasi cukup. Rata-rata observasi pada siklus I adalah $60,9 \%$ berada pada klasifikasi cukup dan rata-rata angket respon siswa adalah $51,65 \%$ berada pada klasifikasi hampir cukup.

Selama proses belajar mengajar berlangsung terlihat bahwa pengaruh dari keunggulan teknik tanya jawabberbantuan media gambar ini dapat dirasakan oleh siswa. Berdasarkan teori, keunggulan dari teknik tanya jawabberbantuan media gambar yaitu, mendapat sambutan kelas, pada saat guru melakukan tanya jawab dengan siswa tentang deskripsi dan gambar yang ditampilkan, siswa sebagai sampel dalam penelitian ini lebih fokus dan tenang karena siswa lebih sibuk untuk memikirkan apa yang akan mereka jawab nanti. Namun, dari hasil penelitian pada siklus I masih belum mencapai KKM. Maka, peneliti harus melakukan siklus II. Untuk melakukan siklus II guru harus lebih memperhatikan kekurangan dan kelebihan yang telah dilakukan pada siklus I. Hasil dari siklus I menyatakan bahwa masih banyak siswa yang belum paham pada indikator pemilihan diksi yang menggugah dan memikat dan ejaan yang disempurnakan. Guru harus menjelaskan kembali tentang menulis deskripsi dan merevisi kembali kekurangan-kekurangan yang terdapat pada siklus I.

Dari hasil siklus II yang telah dilakukan rata-rata untuk indikator (1) memberikan detail atau perincian objek adalah 70,6\% dan berada pada klasifikasi lebih dari cukup, (2) memberi 
pengaruh sensivitas dan imajinasi adalah $76 \%$ dan berada pada klasifikasi baik, (3) pemilihan diksi yang menggugah dan memikat adalah $70 \%$ dan berada pada klasifikasi baik, (4) memaparkan sesuatu yang dapat didengar, dilihat, dan dirasakan adalah $76 \%$ dan berada pada klasifikasi baik, (5) ejaan yang disempurnakan adalah 83,3\% dan berada pada klasifikasi baik. Rata-rata dari siklus II adalah $76 \%$ dan berada pada klasifikasi baik. Rata-rata observasi pada siklus II adalah $86,1 \%$ berada pada klasifikasi baik sekali dan rata-rata angket respon siswa adalah $79,96 \%$ berada pada klasifikasi baik.

Tabel 2. Rata-rata Kemampuan Menulis Karangan Deskripsi dengan Teknik Tanya Jawab Berbantuan Media Gambar Siswa Kelas VIII 3 SMP Negeri 2 Sungayang pada Tes Awal Hingga ke Akhir Siklus II untuk Lima Indikator

\begin{tabular}{|c|l|c|c|c|c|}
\hline No & \multicolumn{1}{|c|}{ Indikator } & Prasiklus & Siklus I & Siklus II & Keterangan \\
\hline 1. & Memberikan rincian objek & 28 & 67,3 & 76 & $\begin{array}{c}\text { Naik 3,3\% } \\
\text { Tuntas }\end{array}$ \\
\hline 2. & $\begin{array}{l}\text { Memberikan pengaruh } \\
\text { sensitivitas }\end{array}$ & 26,6 & 46,6 & 76 & $\begin{array}{c}\text { Naik } 16 \% \\
\text { Tuntas }\end{array}$ \\
\hline 3. & $\begin{array}{l}\text { Menggunakan pilihan kata yang } \\
\text { menggugah }\end{array}$ & 29,3 & 61,3 & 70,6 & $\begin{array}{c}\text { Naik 8,7\% } \\
\text { Tuntas }\end{array}$ \\
\hline 4. & $\begin{array}{l}\text { Memaparkan sesuatu yang dapat } \\
\text { didengar, dilihat, dan dirasakan }\end{array}$ & 32 & 60 & 76 & $\begin{array}{c}\text { Naik } 16 \% \\
\text { Tuntas }\end{array}$ \\
\hline 5. & $\begin{array}{l}\text { Ejaan Yang Disempurnakan } \\
\text { Jumlah }\end{array}$ & $\begin{array}{c}151,9: 5= \\
31,98\end{array}$ & $\begin{array}{c}1848: 5= \\
369\end{array}$ & $\begin{array}{c}2280: 5= \\
456\end{array}$ & $\begin{array}{c}\text { Naik } 24 \% \\
\text { Nuntas } 87 \% \\
\text { Tuntas }\end{array}$ \\
\hline \multicolumn{2}{|c|}{ Rata-rata } & $30,4 \%$ & $61,6 \%$ & $76 \%$ & Naik 14,4\% \\
\hline
\end{tabular}

Berdasarkan keterangan tersebut membuktikan bahwa teknik tanya jawab dengan media gambar layak direkomendasikan dan dikembangkan dalam pembelajaran, khususnya pembelajaran keterampilan menulis karangan deskripsi. Kelayakan penerapan teknik tanya jawab dengan media gambar juga didukung oleh tanggapan siswa yang diperoleh dari pengisian angket pembelajaran dan lembaran observasi. Hal-hal yang tidak dimengerti oleh siswa sebelum menulis karangan deskripsi dapat dipertanyakan sebelumnya. Akhirnyadengan penggunaan teknik tanya jawab dengan media gambar dapat meningkatkan keterampilan siswa dalam menulis karangan deskripsi.

\section{Simpulan dan Saran}

Penggunaan teknik tanya jawab dengan media gambar dalam menulis karangan deskripsi sangat diperlukan. Teknik atau media ini selain meningkatkan kemampuan menulis deskripsi juga melatih siswa untuk lebih leluasa mengemukakan pendapat mereka dan lebih dapat menghargai pendapat orang lain. Hal ini terlihat dalam aktivitas proses tanya jawab tentang materi maupun dalam menulis karangan deskripsi.

Media gambar yang digunakan sebagai pendukung dalam pelaksanaan tanya jawab dalam menulis karangan deskripsi sangat membantu siswa meningkatkan kemampuan siswa dalam menulis karangan deskripsi. Berdasarkan pembahasan dan simpulan hasil penelitian, diharapkan kepada guru dapat mengarahkan dan melatih siswa dalam menulis karangan deskripsi dan menggunakan teknik atau media yang menarik dalam melaksanakan latihan menulis terutama menulis karangan deskripsi agar dapat meningkatan hasil menulis yang baik. 
Catatan: artikel ini disusun berdasarkan hasil penelitian untuk penulisan skripsi penulis dengan Daftar Rujukan Pembimbing I Prof. Dr. Atmazaki, M.Pd., dan Pembimbing II Drs. Amril Amir, M.Pd.

Abdurrahman dan Ellya Ratna. 2003. "Evaluasi Pembelajaran Bahasa dan Sastra Indonesia "(BukuAjar). Padang: FBSS Padang.

Achmadi, Muchsin. 1988. "Materi Dasar Pengajaran Komposisi Bahasa Indonesia". Jakarta: Departemen Pendidikan dan kebudayaan; Direktorat Jendral Pendidikan Tinggi, Proyek pengembangan Lembaga Pendidikan Tenaga kependidikan.

Arikunto, Suharsimi. 1998. Penelitian Tindakan Kelas. Jakarta: Bumi Aksara.

Arikunto, Suharsimi. 2006. Prosedur Penelitian Suatu Pendekatan Praktik Edisi Revisi IV. Jakarta: Rineka Cipta.

Arsyad, Azhar. 2007. Media Pembelajaran. Jakarta: PT.Raja Grafindo Persada.

Keraf, Gorys. 1982. Eksposisi dan Deskripsi. Ende Flores: Nusa Indah.

Marahimin, Ismail. 2010. Menulis Secara Popular. Jakarta: Pustaka Jaya.

Sadiman, Arief S, dkk.2007. Media Pendidikan. Jakarta: CV. Rajawali.

Saliwangi, Basennang.1989. Pengantar Strategi Belajar-Mengajar. Malang: IKIP Malang.

Semi, M. Atar. 2009. Menulis Efektif. Padang: Angkasa Raya.

Suyatno.2004. Teknik Pembelajaran Bahasa dan sastra. Surabaya: SIC.

Thahar, Harris Effendi. 2008. Menulis Kreatif Panduan Bagi Pemula. Padang: UNP Press.

Tarigan, Djago. 1986. Membina Keterampilan Menulis Paragraf dan Pengembangannya. Bandung: Angkasa.

Tarigan, Henry Guntur. 2008. Menulis Sebagai Suatu Keterampilan Berbahasa. Bandung: Angkasa Raya. 